\title{
A Study of Hearing Status in Children at Sungsim Deaf Rehabilitation Center
}

\author{
Seungwan Lee1, Jinbea Shin', Kyeongyeon Park1, Jieun Yoon', Jinsook Kim¹,2 \\ 'Department of Speech Pathology and Audiology, Graduate School, Hallym University, Chuncheon, Korea \\ ${ }^{2}$ Division of Speech Pathology and Audiology, Research Institute of Audiology and Speech Pathology, College of Natural Science, Hallym University, \\ Chuncheon, Korea
}

\author{
성심농아재활원생들의 청력 실태 조사연구 \\ 이승완 ${ }^{1}$ 신진배 ${ }^{1} \cdot$ 박경연 $^{1} \cdot$ 윤지은 ${ }^{1} \cdot$ 김진숙 $^{1,2}$ \\ 한림대학교 일반대학원 언어병리청각학과', 한림대학교 자연과학대학 언어청각학부 · 청각언어연구소 ${ }^{2}$
}

\begin{abstract}
Purpose: The purpose of was to assess the hearing impairment status, investigate the situation of aural rehabilitation service, and improve the communicational environment of Sungsim Deaf Rehabilitation Center. Methods: The total members who participated were 58 (mean age: 14.72, age range: 7-36), with 35 males and 23 females. Out of 58 members, only 52 were fitted with hearing devices and 13 had multiple disabilities. Otoscopic examination, pure tone audiometry (PTA), tympanometry, functional gain test, and International Outcome Inventory for Hearing Aids (IOI-HA) were performed. Speech recognition threshold (SRT) and word recognition score (WRS) were measured in the sound field with operating hearing devices. Results: Both of otoscopic examination and tympanometry showed normal at 105 ears (91\%). PTA for air conduction thresholds were 109.81 and $110.34 \mathrm{~dB}$ HL at right and left ears. Functional gain values were $52.14 \mathrm{~dB}$ in a total average of 52 members. According to type of hearing devices, $72.16 \mathrm{~dB}$ for cochlear implanted unilaterally (19), $69.03 \mathrm{~dB}$ for cochlear implanted bilaterally (3), $61.68 \mathrm{~dB}$ for bimodal fitting (6), $32.73 \mathrm{~dB}$ for hearing aided unilaterally (6) $32.04 \mathrm{~dB}$ for hearing aided bilaterally (18) were revealed in order. The SRT and WRS were $52.41 \mathrm{~dB} \mathrm{HL}$ and $35 \%$. IOI-HA scores of each item was 3.81 in average showing good satisfaction level of the hearing devices. Conclusion: Conclusively, the fitting status of hearing devices was not sufficient to understand speech sound although their external and middle ears were in good condition. Improving and refitting their hearing devices were recommended and periodical monitoring of hearing and hearing devices were thought to be necessary.
\end{abstract}

Key Words: Sungsim Deaf Rehabilitation Center, Hearing impairment status, Hearing devices, International Outcome Inventory for Hearing Aids.

Received: July 7, 2017 / Revised: July 12, 2017 / Accepted: July 14, 2017

Correspondence: Jinsook Kim, Division of Speech Pathology and Audiology, Research Institute of Audiology and Speech Pathology, College of Natural Science, Hallym University, 1 Hallimdaehak-gil, Chuncheon 24252, Korea

Tel: +82-33-248-2213 / Fax: +82-33-256-3240 / E-mail: jskim@hallym.ac.kr

\section{INTRODUCTION}

청각장애는 2015년 등록된 15가지 장애유형 중 지체장애, 시 각장애, 뇌병변 장애에 이어 253,334(10.1\%)명으로 네 번째의 빈도를 보이는 장애였으나, 최근 2016년에는 지체장애에 이어 271,843(10.8\%)명으로 두 번째의 빈도를 보이는 장애로 보고되었 다(Ministry of Health and Welfare, 2016a; Ministry of Health and Welfare, 2017). 또한 청각장애는 지적장애, 지체장애, 자폐 성 장애, 발달지체에 이어 다섯 번째로 높은 특수교육 대상자 로 분류되고 있다. 현재 우리나라의 특수교육 인원의 총 대상
자는 87,950명이고 그중 청각장애 특수교육 대상자 수는 총 3,401(3.9\%)명이다. 이 중 특수학교에서 교육을 받는 경우가 863(25.3\%)명이고 일반학교의 특수학급에서 교육을 받는 경우 가 700(20.6\%)명이며, 일반학교의 일반학급(전일제 통합학급) 에서 교육을 받는 경우가 $1,816(53.4 \%)$ 명으로 일반학교에서 교 육을 받는 경우가 청각장애 특수교육 대상자 중 $74 \%$ 에 달하며 특수교육 지원센터에서 교육을 받는 경우가 22(0.6\%)명으로 매 우 적은 수가 특수교육 지원센터를 이용하고 있다(Ministry of Education, 2016). 이와 같이 요즈음의 특수교육 형태는 특수 교육기관인 특수학교나 특수교육지원센터에서 이루어지기보다 
는 일반학교의 통합교육으로 점점 전환되고 있다. 특수교육 통 계에서 보고되고 있지는 않지만 사회복지법인 혹은 재단법인으 로 운영되는 청각장애 지원기관도 청각장애의 교육을 담당하 는 중요한 기관으로 알려져 있다. 예를 들어 대표적인 청각장애 아동이나 성인들이 거주하며 도움을 받는 수용시설로 삼성농 아원, 메아리동산, 성동원, 성심농아재활원 등이 있는데 2016년 기준으로, 삼성농아원에 35명, 메아리동산에 39명, 성동원에 19 명, 성심농아재활원에 73 명으로 총 166 명의 청각장애아동 및 성 인이 청각장애 지원기관에 거주하며 도움을 받고 있다(Ministry of Health and Welfare, 2016b). 이 중 충주에 위치해 있는 성심 농아재활원이 가장 큰 규모이며 39명의 기관 종사자가 함께 생 활하고 있다. 따라서 청각장애 지원기관에서 생활하는 원생들 의 청력과 보장구 형태 및 의사소통 방식에 따른 적절한 자극 과 재활서비스가 제공되고 있는지 검토해 볼 필요가 있다. 왜냐 하면 재활원생의 청력과 의사소통 방식 및 보장구 이득을 고려 하지 않고 청각 및 언어재활 서비스가 제공될 시 재활의 효율성 이 떨어지기 때문이다. 예를 들어 보장구 형태에 따른 이득 수 준을 고려하지 않고 단지 높은 수준의 강도로 의사소통을 하게 될 경우, 불쾌 수준(most uncomfortable level)에 도달할 수 있 고, 오히려 어음을 이해하는 데 어려움이 있을 수 있으며(Studebaker et al., 1999) 이로 인해 보장도 만족도가 감소할 수 있다. 또한 재활 시 의사소통 방식을 고려하지 않을 경우, 수화만 사 용하는 원생에게 구화로만 접근하거나 구화가 가능한 원생에 게 계속 수화를 사용할 경우 적절한 청각과 언어기능 발달에 지장을 줄 수 있기 때문이다.

본 조사는 성심농아재활원의 요청으로 이루어졌으며 기관의 질 높은 재활서비스를 위해 원생들의 청력평가와 보청기 착용 등의 청각 서비스 실태조사를 실시하고자 하여, 그 취지를 존중 하며 진행하였다. 본 사례연구의 목적은 성심농아 재활원생들의 청력상태를 확인하고, 청각 및 언어 재활 서비스의 실태와 효율 성을 분석하여 재활원생들의 의사소통 능력을 향상하고 보장구 의 착용 만족도를 높여 성심농아재활원생들의 복지를 향상하고
자 함에 있다.

\section{MATERIALS AND METHODS}

\section{연구 대상}

2016년 6월 24일 검사를 진행하였으며 재활원의 검사 대상인 원은 검사일 기준으로 재활원 내 기숙하거나 통학하는 경우를 포함하여 총 58명(평균 연령 14.72세, 연령범위 7 36세, 남 35, 여 23)이었다. 이 중 청각장애 외에 중복장애를 가진 대상자의 수는 13 명으로 뇌병변 장애 2 명, 지적장애 5 명, 적응장애 1 명, 언어장애 4 명, 지적 및 지체장애 1 명이었다. 보장구 착용형태로 분류할 때, 편측 인공와우 착용자는 19 명, 양측 인공와우 착용 자는 3 명, 양측 보청기 착용자는 18 명, 편측 보청기 착용한 경 우, 이형(bimodal)으로 한쪽은 인공와우를 다른 한쪽은 보청기 를 착용한 경우, 그리고 아무런 보장구도 착용하지 않는 경우가 각각 6명씩이었다(Table 1). 총 58명의 대상자들이 사용하는 의 사소통 방식은 수화와 구화를 통합하여 사용하는 경우가 42 명, 수화만 사용하는 경우가 15 명, 구화만 사용하는 경우가 1 명이었 다. 진행을 순조롭게 하기 위해 방문 일주일 전 검사대상자들의 기본적인 정보(나이, 성별, 보장구 착용 형태, 의사소통 방식)를 미리 조사하였으며, 보청기 만족도 조사를 위하여 한국어로 번 역된 국제 표준 보청기 효과 지수(Korean International Outcome Inventory for Hearing Aids, K-IOI-HA) 설문지를 이용 하였다(Bentler et al., 2016). IOI-HA 설문지는 성심농아재활원 생들에게 미리 배포하여 검사 전 작성하도록 하였다.

\section{연구 방법}

상용화된 이경 검사 도구(WEL22820; Welch Allyn, Skaneateles Falls, NY, USA)를 통해 외이도 내 귀지 및 고막의 상 태를 확인하고, 고막운동도 검사를 휴대용 고막운동검사기기 (MT10; Interacoustics, Assens, Denmark)로 실시하여 중이 구 조물의 상태를 평가하는 고막운동도(tympanometry) 검사를 실

Table 1. Subjects' information of hearing devices

\begin{tabular}{|c|c|c|c|c|c|c|c|}
\hline \multirow{2}{*}{ Type of hearing device } & \multirow{2}{*}{$\mathrm{HI}$} & \multicolumn{5}{|c|}{ Types of disability } & \multirow{2}{*}{ Tota } \\
\hline & & $\mathrm{BL}$ & ID & $\mathrm{AD}$ & LD & IPD & \\
\hline CI-U & 15 & 1 & - & - & 3 & - & 19 \\
\hline CI-B & 3 & - & - & - & - & - & 3 \\
\hline $\mathrm{HA}-\mathrm{U}$ & 4 & 1 & 1 & - & - & - & 6 \\
\hline HA-B & 16 & - & 2 & - & - & - & 18 \\
\hline Bimodal & 5 & - & - & 1 & - & - & 6 \\
\hline None & 2 & - & 2 & - & 1 & 1 & 6 \\
\hline Total & 45 & 2 & 5 & 1 & 4 & 1 & 58 \\
\hline
\end{tabular}

CI-U: cochlear implanted unilaterally, CI-B: cochlear implanted bilaterally, HA-U: hearing aided unilaterally, HA-B: hearing aided bilaterally and disabilities, HI: hearing impairment, MD: multiple disability, BL: brain lesions, ID: intellectual disability, AD: adjustment disorder, LD: language disorder, IPD: intellectual and physical disability 
시하였다. 이동용 순음검사기기(SA 204; Entomed AB, Malmo, Sweden)로 기도와 골도 순음청력검사를 실시하였다. 효율적이 고 신속한 검사진행을 위해 기도는 $250,500,1,000,2,000,4,000$, $8,000 \mathrm{~Hz}$, 골도는 $500,1,000,2,000 \mathrm{~Hz}$ 의 역치를 측정하였다. 또 한 보장구 기능이득을 검사하기 위해 보청기를 착용하고 음장 에서 스피커를 $0^{\circ}$ 로 위치한 상태에서 성심농아재활원에 비치 된 순음청력검사기(Harp; Inventis, Padova, Italy)를 이용하여 wable tone으로 보장구의 기능 이득 역치를 측정하였다. 동일 한 검사상황에서 스피커를 통하여 한국어음청각검사(Korean speech audiometry, KSA)로 어음인지역치(speech recognition threshold, SRT)와 단어인지도(word recognition score, WRS) 를 피검자의 연령에 맞는 목록을 사용하여 실시하였다(Lee et al., 2010). 어음청각검사에서 따라 말하기가 어려운 원생들의 경우 어음을 들려주고 들리면 버튼을 누르는 형식의 어음탐지 역치(speech detection threshold, SDT)를 측정하였고, 해당 검 사마저 진행할 수 없는 경우 어음 검사를 실시하지 못하였다. 단어인지도는 보장구를 착용한 후 쾌적수준(most comfortable level, $\mathrm{MCL}$ )으로 반응하는 정도인 60 75 dB HL에서 검사하였 다. 순음청력검사 2 개조, 보장구 기능이득 검사 및 KSA 1 개조, 이경 및 중이 검사 1 개조 총 4 개조를 구성하여 하루에 검사를 실시할 수 있도록 하였다. 각 검사의 진행 시 배경소음을 최소 화하기 위하여 조용한 사무실에서 검사를 진행하였고 해당 검 사가 끝난 후 다음 검사의 안내 및 검사 인원의 관리는 성심농 아재활원에서 직접 진행하였다. 각 검사에서 피검자가 수화만으 로 의사소통을 하거나 대상자가 중복장애가 있어 검사자 간의 의사소통이 어려울 경우 수화통역을 하여 검사를 원활히 진행 할 수 있도록 보조하였다.

\section{연구 절차 및 분석}

평균순음역치는 $500,1000,2,000 \mathrm{~Hz}$ 를 이용하여 삼분법으 로 분석하였고 한 주파수에서 검사기기의 최대강도에서도 반응 하지 않을 경우 두 주파수를 이용해 평균순음역치를 평가하였 다. 하나 혹은 두 주파수 이상에서 검사기기의 최대강도에서 반 응하지 않는 경우 해당 주파수 최대강도에 $10 \mathrm{~dB} \mathrm{HL}$ 을 더해 250 $\mathrm{Hz}$ 에서는 $110 \mathrm{~dB} \mathrm{HL}$ 로 8,000 Hz에서는 $120 \mathrm{~dB} \mathrm{HL}, 500$, $1,000,2,000,4,000 \mathrm{~Hz}$ 에서는 $130 \mathrm{~dB} \mathrm{HL}$ 로 계산하였다. 골도 평균역치는 $500,1,000,2,000 \mathrm{~Hz}$ 를 이용하여 삼분법으로 분석 하였고 검사기기의 최대강도에서 반응하지 않은 주파수의 경우 최대강도에 $10 \mathrm{~dB} \mathrm{HL}$ 을 더해 $500 \mathrm{~Hz}$ 에서는 $70 \mathrm{~dB} \mathrm{HL}, 1,000$, $2,000 \mathrm{~Hz}$ 에서는 $80 \mathrm{~dB}$ HL로 계산하였다. 보장구 기능 이득 역 치는 보장구가 없는 6 명과 검사가 불가한 경우 6 명을 제외하여 총 46 명을 대상으로 실시한 후 분석하였다. 보장구 기능 이득 평균 역치는 $500,1,000,2,000 \mathrm{~Hz}$ 를 이용하여 삼분법으로 분석
하였다. 검사기기의 최대강도에서 반응하지 않았던 주파수에서 최대강도에 $10 \mathrm{~dB} \mathrm{HL}$ 을 더해 250과 8,000 Hz에서는 $95 \mathrm{~dB}$ $\mathrm{HL}$ 로 500, 1,000, 2,000, 4,000 Hz에서는 $105 \mathrm{~dB} \mathrm{HL}$ 로 계산 하였다. IOI-HA는 보장구 미착용자 6명과 중복장애로 인해 설 문지를 이해할 수 없어 작성하지 못한 2명을 제외하고 보청기뿐 만 아니라 인공와우 및 이형 착용자를 포함한 총 50명이 작성한 자료를 분석하였다. 설문지는 각 7문항으로, 1) 하루 착용시간 (daily use), 2) 착용효과(benefit), 3) 착용 시 활동의 제한 정도 (residual activity limitations), 4) 만족도(satisfaction), 5) 착용 시 사회적 참여의 방해 정도(residual participation restrictions), 6) 주변사람들에게 주는 영향력(impact on others), 7) 삶의 질의 향상도(quality of life)로 구성되어 있으며 각 문항에 따른 결과 를 보장구 착용 형태별로 유의한 차이를 보이는지 분석하였고 총점이 보장구 착용 형태에 따라 유의미한지 분석하였다.

통계분석은 SPSS version 23.0 (IBM Corp., Armonk, NY, USA)을 이용하여 분석하였다. 보장구 착용 형태별 보장구 기능 이득 역치가 유의미한 차이를 보이는지 보기 위해 ShapiroWilk test로 각 그룹의 정규성 검정 후 일원배치 분산분석(oneway ANOVA)을 통해 그룹 간 유의미한 차이를 분석하였다. 또 한 IOI-HA 총점이 보장구 착용 형태별로 유의미한 차이를 보 이는지 확인하기 위해 Shapiro-Wilk test로 각 그룹의 정규성 검 정 후 일원배치 분산분석(one-way ANOVA)을 통해 그룹 간 유 의미한 차이를 분석하였다. IOI-HA의 각 문항당 보장구 형태별 차이가 있는지 보기 위해 다변량 분산분석(MANOVA)을 사용 하였다. 문항에 따라 등분산이 가정되지 않은 경우 Bonferroni 사후 검정을 실시하였고 유의수준 0.05 미만에서 분석하였다.

\section{RESULTS}

이경 검사 결과 우측은 외이도 내 귀지가 부분적으로 위치하 고 있는 경우가 30 명, 귀지로 인해 외이도가 완전히 막힌 경우 가 1 명, 외이도 내 출혈과 고름이 있는 경우가 1 명, 고막이 관찰 되지 않은 경우 1 명, 고막을 잘 관찰할 수 있을 만큼 외이도의 상태가 건강한 경우가 25 명으로 나타났다. 좌측의 경우 외이도 폐쇄증으로 검사가 불가능한 경우 1 명을 제외하고 외이도 내 귀 지가 부분적으로 위치하고 있는 경우가 28명, 고막을 잘 관찰 할 수 있을 만큼 외이도의 상태가 건강한 경우가 29명으로 나 타났다.

고막운동도 검사 결과, 우측은 A형이 52(89.7\%)명, B형이 $5(8.6 \%)$ 명, C형이 1(1.7\%)명이었다. B형을 보인 대상자들은 이경 검사 시 출혈이나 고름을 보인 경우와 귀지로 인해 고막을 관찰 할 수 없었던 경우 2 명이 모두 포함되었다. 좌측의 경우 $\mathrm{A}$ 형이 53(91.3\%)명, B형이 2(3.5\%)명, Ad형이 1(1.7\%)명이었고 외이도 
폐쇄증 및 외이도 용적 초과로 검사가 불가한 경우가 2(3.5\%)명 이었다. Table 2 는 검사대상자 총 58 명(116귀)의 이경 검사 결과 와 고막운동도 검사 결과를 나타낸 표이다.

순음청력검사는 중복장애로 인해 검사 진행이 불가능한 4명 을 제외하고 총 54 명이 참여하였는데, 우측의 기도 청력 평균역 치는 $500,1,000,2,000 \mathrm{~Hz}$ 에서 모두 반응하여 총 37 명의 삼분 법 분석 결과가 $95.70 \mathrm{~dB}$ HL이었으며 그 외 하나 혹은 두 주파 수 이상에서 청력검사기의 최대 강도에서 반응이 없는 17 명의 경우 해당 주파수에 $10 \mathrm{~dB}$ 을 더하여 표기하여 $123.92 \mathrm{~dB} \mathrm{HL}$ 의 평균순음역치를 나타냈다. 따라서 54 명의 우측 기도 청력 평균 역치는 $109.81 \mathrm{~dB}$ 로 나타났다.

54 명 중 좌측에서 기도 역치를 $500,1,000,2,000 \mathrm{~Hz}$ 에서 모 두 반응하여 삼분법한 평균순음역치는 총 41 명에서 분석할 수 있었고 그 결과는 $95.30 \mathrm{~dB}$ HL이었으며 그 외 하나 혹은 두 주 파수 이상에서 청력검사기의 최대 강도에서 반응이 없는 13 명 의 경우 해당 주파수에 $10 \mathrm{~dB}$ 을 더해 $125.38 \mathrm{~dB} \mathrm{HL}$ 의 평균순 음역치를 나타냈다. 따라서 54명의 좌측 기도 청력 평균 역치는 $110.34 \mathrm{~dB}$ 로 나타났다.

우측 골도 검사는 총 58 명 중 중복장애 및 골 진동체 부착에 통증을 호소하여 검사 협조가 어렵거나 소리에 굉장히 민감한 반응을 보여 검사 진행이 어려운 7명을 제외하고 51명에게 실시 하였다. 우측의 골도 청력 평균역치는 $500,1,000,2,000 \mathrm{~Hz}$ 에서 모두 반응하여 삼분법한 총 10 명에서 분석한 결과가 $54.33 \mathrm{~dB}$ $\mathrm{HL}$ 이었다. 그 외 하나 혹은 두 주파수 이상에서 청력검사기의 최대 강도에서 반응이 없는 41 명의 경우 해당 주파수에 $10 \mathrm{~dB}$ $\mathrm{HL}$ 을 더해 $70.23 \mathrm{~dB}$ HL의 평균 골도역치를 나타냈다. 따라서 51 명의 우측 골도 청력 평균 역치는 $62.28 \mathrm{~dB}$ 로 나타났다.

좌측 골도 검사는 총 58 명 중 중복장애 및 골 진동체 부착에 통증을 호소하여 검사 협조가 어렵거나 검사를 진행할 수 없는 5 명을 제외하고 총 53 명에게 실시하였다. 우측의 골도 청력 평균 역치는 $500,1,000,2,000 \mathrm{~Hz}$ 에서 모두 반응하여 삼분법한 총 11 명에서 평균순음역치를 분석한 결과는 $56.51 \mathrm{~dB}$ 이었다. 그 외 하 나 혹은 두 주파수 이상에서 청력검사기의 최대 강도에서 반응 이 없는 42 명의 경우 해당 주파수에 $10 \mathrm{~dB} \mathrm{HL}$ 을 더해 $70 \mathrm{~dB} \mathrm{HL}$ 의 평균 골도역치를 나타냈다. 53 명의 좌측 골도 청력 평균 역치
는 $63.25 \mathrm{~dB}$ 로 나타났다.

보장구 기능이득 검사는 총 58명 중 보장구가 없거나 중복장 애로 인해 검사가 불가한 12 명을 제외하여 46 명에게 실시하였 다. 보장구 기능 이득 검사의 $500,1,000,2,000 \mathrm{~Hz}$ 의 전체 평균 역치는 $49.90 \mathrm{~dB}$ HL이었다. 보장구 착용 형태별로 나누어 분석 할 때, 편측으로 인공와우를 착용한 인원 17 명의 보장구 기능 이득 역치는 $41.86 \mathrm{~dB}$ HL이었고 양측으로 인공와우를 착용한 인원 3 명의 보장구 기능이득 역치는 $40.55 \mathrm{~dB} \mathrm{HL}$ 이었다. 편측으 로 보청기를 인원 5 명의 보장구 기능 이득 평균 역치는 $64.33 \mathrm{~dB}$ $\mathrm{HL}$ 이었고 양측 보청기 착용 인원 16 명의 보장구 기능 이득 역 치는 $60.10 \mathrm{~dB}$ HL이었다. 이형으로 착용한 5 명의 보장구 기능 이득 역치는 $42.66 \mathrm{~dB} \mathrm{HL}$ 이었다. 따라서 가장 기능이득이 좋은 경우는 양측 인공와우 형태의 보장구 착용이고 가장 기능 이득 이 낮은 경우는 편측 보청기 형태의 보장구 착용이었다. Figure 1 은 청각장애만 가진 경우와 청각장애와 다른 장애가 연합된 중복장애를 가진 경우에 따라 각 주파수별로 순음평균 청력 역 치와 보장구 기능이득 역치를 비교한 그래프이다. Figure 2는 보 장구 착용 형태에 따라 각 주파수별로 순음평균 청력 역치와 보 장구 기능이득 역치를 비교한 그래프이다.

재활원생들의 대부분이 고도에서 심도 이상의 청력손실을 보였으나 각 보장구 착용 형태별로 분석한 보장구 기능 이득의 차이는 범위가 크게 나타났다. $60 \mathrm{~dB}$ 이상의 큰 기능이득값을 보인 경우는 인공와우 편측과 양측 착용자들에서 각각 72.16 $\mathrm{dB}$ 와 $69.03 \mathrm{~dB}$, 이형의 착용자들에서 $61.78 \mathrm{~dB}$ 이었다. 그러나 편 측 혹은 양측 보청기를 착용한 경우 이득이 $30 \mathrm{~dB}$ 정도로 적게 나타났다(Table 3). 보장구 기능 이득의 차이를 보기 위해 정규성 검정 후 일원배치 분산분석(one-way ANOVA)을 시행하였다. 모든 그룹은 Shapiro-Wilk test에서 정규분포를 따랐으며, 보장 구 착용 형태별 보장구 기능 이득 역치는 유의미한 차이를 보 였다 $[\mathrm{F}(45,4)=4.895, p=0.003]$. Bonferroni 사후검정을 하였 을 때, 유의미한 차이를 보인 그룹은 편측 인공와우와 편측 보청 기, 양측 보청기 간 보장구 기능 이득 역치가 유의한 차이를 보였 다 $(p<0.05)$.

보장구를 착용한 상태에서 $\mathrm{KSA}$ 로 스피커를 이용하여 어음 검사를 실시하였다. SRT는 총 30명에게 실시하였고 단어를 따

Table 2. Results of otoscopic examination and tympanometry

\begin{tabular}{|c|c|c|c|c|c|c|}
\hline \multirow{2}{*}{ Otoscopic examination } & \multicolumn{5}{|c|}{ Types of tympanogram } & \multirow{2}{*}{ Total (\%) } \\
\hline & $\mathrm{A}$ & $\mathrm{B}$ & $\mathrm{C}$ & Ad & Other & \\
\hline Normal & $51(44.0)$ & $3(2.6)$ & - & - & $1(0.9)$ & $55(47.4)$ \\
\hline PIC & $54(46.5)$ & $2(1.7)$ & $1(0.9)$ & $1(0.9)$ & - & $59(50.8)$ \\
\hline IC & - & $1(0.9)$ & - & - & - & $1(0.9)$ \\
\hline Other & - & - & - & - & $1(0.9)$ & $1(0.9)$ \\
\hline Total & $105(90.5)$ & $7(6.0)$ & $1(0.9)$ & $1(0.9)$ & $2(1.7)$ & $116(100)$ \\
\hline
\end{tabular}

PIC: partially impacted cerumen, IC: impacted cerumen 
라 말할 수 없어 검사가 불가능했던 28명은 SDT 검사를 실시하 였다. 그러나 실질적으로 SDT를 실시할 수 있는 인원은 단 1명 뿐이었다. SRT의 평균은 $52.41 \mathrm{~dB}$ HL로 나타났고 1 명에게 실
시한 SDT는 $40 \mathrm{~dB}$ 로 나타났다. 보장구 착용 형태별로 나누어 분석하였을 때 편측으로 인공와우를 착용한 경우 평균은 44.58 $\mathrm{dB}$ HL이었으며 양측에 인공와우를 착용한 경우는 $47.50 \mathrm{~dB}$
Figure 1. Comparison of thresholds of pure tone (black) and functional gain (gray) of the $\mathrm{HI}$ and MD. HI: hearing impairment, MD: multiple disabilities.
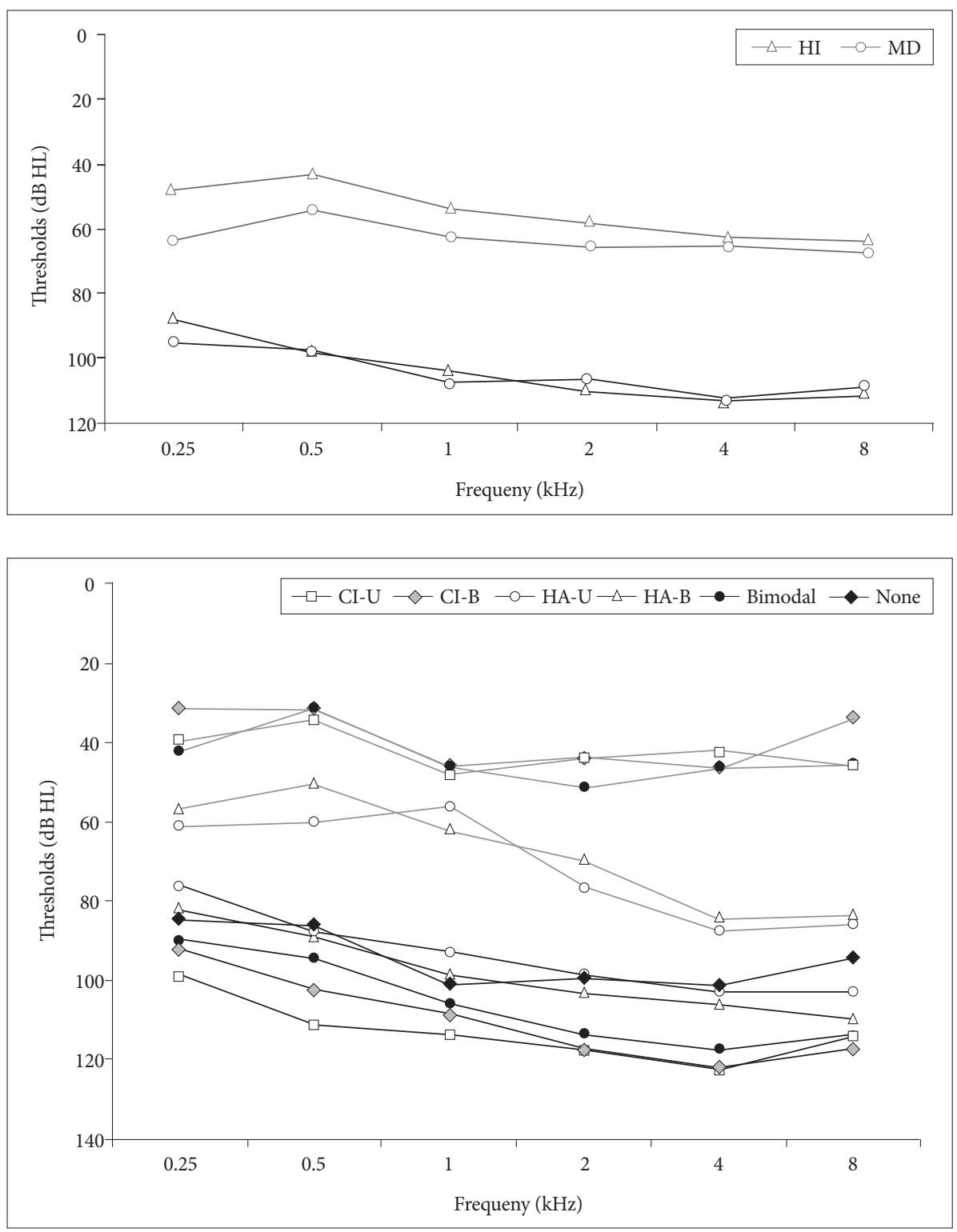

Figure 2. Comparison of thresholds of pure tone (black) and functional gain (gray) according to types of hearing devices. Cl-U: cochlear implanted unilaterally, Cl-B: cochlear implanted bilaterally, HA-U: hearing aided unilaterally, HA-B: hearing aided bilaterally.
Table 3. Mean thresholds of pure tone test and functional gain test and gain values between the tests according to types of hearing devices

\begin{tabular}{lccc}
\hline \multirow{2}{*}{ Hearing device } & \multicolumn{3}{c}{ Type of test and gain value } \\
\cline { 2 - 4 } & Pure tone test & Functional gain test & Gain values between the tests \\
\hline CI-U & 114.02 & 41.86 & 72.16 \\
CI-B & 109.58 & 40.55 & 69.03 \\
HA-U & 92.83 & 60.10 & 32.73 \\
HA-B & 96.37 & 64.33 & 32.04 \\
Bimodal & 104.44 & 42.66 & 61.78 \\
None & 95.43 & - & - \\
Total & 102.04 & 49.90 & 52.14 \\
\hline
\end{tabular}

CI-U: cochlear implanted unilaterally, CI-B: cochlear implanted bilaterally, HA-U: hearing aided unilaterally, HA-B: hearing aided bilaterally 


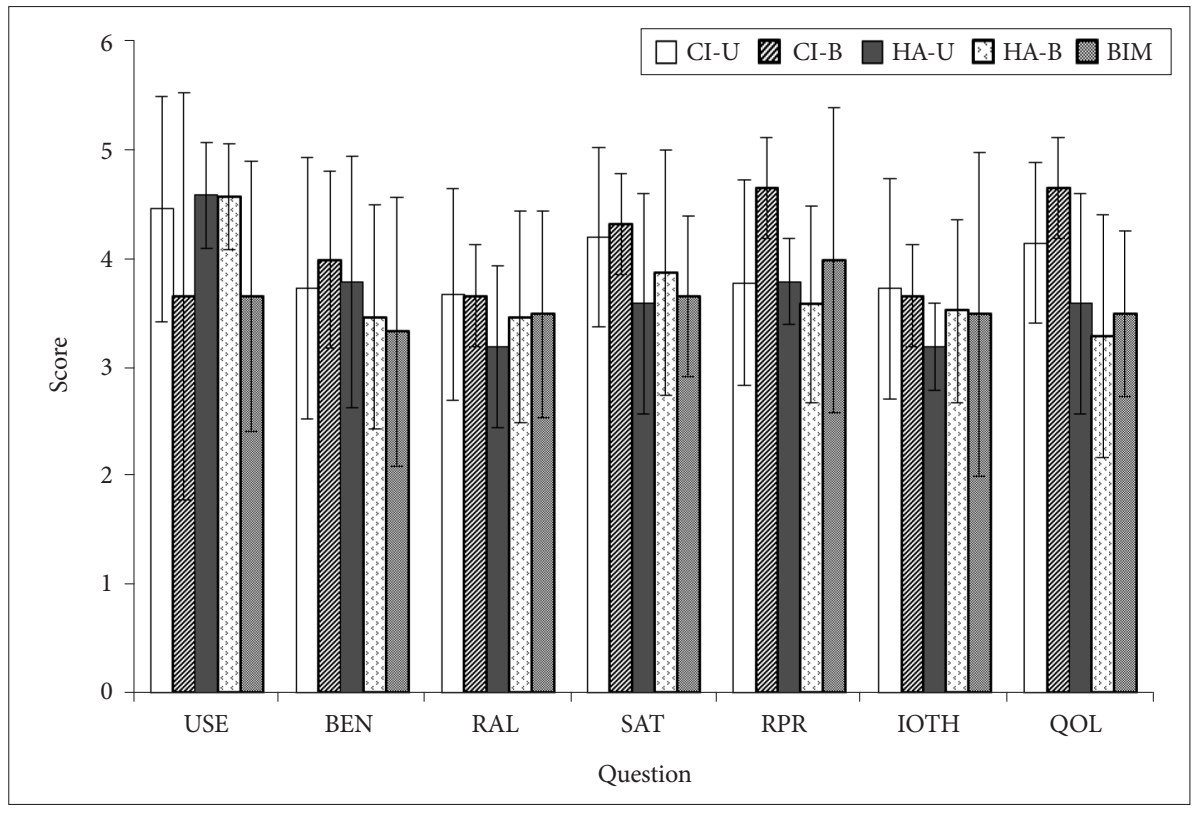

Figure 3. Each question's score of IOI$\mathrm{HA}$ according to types of hearing devices. IOI-HA: International Outcome Inventory for Hearing Aids, $\mathrm{Cl}$-U: cochlear implanted unilaterally, Cl-B: cochlear implanted bilaterally, HA-U: hearing aided unilaterally, HA-B: hearing aided bilaterally, BIM: bimodal, USE: daily use, BEN: benefit, RAL: residual activity limitations, SAT: satisfaction, RPR: residual participation restrictions, IOTH: impact on others, QOL: quality of life.
$\mathrm{HL}$ 이었다. 편측 보청기 착용의 경우는 $48.33 \mathrm{~dB}$ HL이었으며 양 측 보청기 착용의 경우는 $61.66 \mathrm{~dB} \mathrm{HL}$ 이었다. 또한 이형 착용자 평균은 $60 \mathrm{~dB} \mathrm{HL}$ 이었다. $\mathrm{WRS}$ 는 보장구를 착용한 후 $\mathrm{MCL}$ 로 반응하는 60 75 dB HL에서 검사한 편측 혹은 양측 인공와우 착용자는 $46 \%$ 로 나타났으며 편측 혹은 양측 보청기 착용자는 $25 \%$ 를 보였으며 이형을 사용하는 경우 $33 \%$ 로 나타났다. 전체 WRS 평균은 $35 \%$ 로 나타났다.

$\mathrm{IOI}-\mathrm{HA}$ 의 전체 평균은 $26.66=(\mathrm{SD}: \pm 4.47)$ 점으로 나타났 다. 각 보장구 착용 형태별 IOI-HA는 편측 인공와우 착용자에 서 평균 27.78(SD: \pm 4.37)점을 보였으며 양측 인공와우 착용 자의 평균은 $28.66(\mathrm{SD}: \pm 2.62)$ 점이었고 편측 보청기 착용자의 평균은 25.8(SD: \pm 3.96)점이었으며 양측 보청기 착용자의 평균 은 25.82(SD: \pm 4.3)점이었다. 이형 착용자 평균은 25.16(SD: \pm 5.39)점이었다. 보장구 착용 형태별 IOI-HA 차이가 유의한지 확 인하기 위해 정규성 검정 후 일원배치 분산분석(one way ANO$\mathrm{VA})$ 을 시행하였다. 그 결과 모든 그룹은 Shapiro-Wilk test에서 정규분포를 따랐으나 보장구 착용 형태별 IOI-HA는 유의미한 차이를 보이지 않았다 $[\mathrm{F}(49,4)=0.8, p>0.05]$.

$\mathrm{IOI}-\mathrm{HA}$ 를 보장구 착용 형태에 따라 문항별로 점수를 분석 하였다(Figure 3). 보청기 사용시간에 대한 문항은 편측 보청기 착용자가 평균 4.6(SD: \pm 0.48)점으로 가장 높은 점수를 보였고 양측 인공와우 착용자와 이형 착용자가 평균 $3.67(\mathrm{SD}: \pm 1.88$, \pm 1.24 )점으로 가장 낮은 점수를 보였다. 보청기 착용효과에 대 한 문항은 양측 인공와우 착용자의 평균이 4(SD: \pm 0.81)점으 로 가장 높았고 이형 착용자의 평균이 3.33(SD: \pm 1.24 )점으로 가장 낮았다. 보청기로 인한 활동 제한정도 문항은 편측 인공와
우 착용자 평균이 3.68(SD: \pm 0.97)점으로 가장 높았으며 편측 보청기 착용자 평균이 3.2(SD: \pm 0.74)점으로 가장 낮았다. 만족 도에 관한 문항은 양측 인공와우 착용자 평균이 4.33(SD: \pm 0.83)점으로 가장 높았고 편측 보청기 착용자 평균이 3.6(SD: \pm 1.01)점으로 가장 낮았다. 보청기 착용 시 사회적 참여의 방해 정 도 문항은 양측 인공와우 착용자 평균이 4.66(SD: \pm 0.47)점으 로 가장 높았고 양측 보청기 착용자 평균이 $3.58(\mathrm{SD}: \pm 0.91)$ 점 으로 가장 낮았다. 주변사람들에게 주는 영향력 문항은 편측 인 공와우 착용자 평균이 3.73(SD: \pm 1.01 점으로 가장 높았고 편 측 보청기 착용자 평균이 3.2(SD: \pm 0.84 )점으로 가장 낮았다. 삶의 질의 향상도에 관한 문항은 각 보장구 착용 형태별 유의미 한 차이를 보였고 $[\mathrm{F}(45,4)=2.634, p<0.05]$, 양측 인공와우 착 용자 평균이 4.66(SD: \pm 0.47$)$ 점으로 가장 높았고 양측 보청기 착용자 평균이 3.29(SD: \pm 1.12 )점으로 가장 낮았다.

\section{DISCUSSIONS}

성심농아재활원 내 검사에 참여한 원생들의 외이나 중이 상 태는 정상이 $90.5 \%$ 로 나타나 양호한 편이었으며 전체 청력 평 균 역치는 고도에서 심도의 청력 손실 정도를 보였다. 골도 검 사에서 대부분의 원생이 검사기기의 최대강도에서 반응하지 못 했고 $500 \mathrm{~Hz}$ 의 경우 $40 \mathrm{~dB} \mathrm{HL}$ 이상의 역치를 보여 진동촉각반 응일 수 있다는 것을 고려할 경우 대부분의 난청 유형은 감각신 경성 난청으로 볼 수 있다. 보장구 기능 이득은 평균 $52.14 \mathrm{~dB}$ 로 비교적 괜찮은 편이나 인공와우 편측이나 양측 착용 혹은 이형 착용이 보청기보다 큰 기능이득 역치를 나타내고 있어 고 
도에서 심도의 청력손실의 경우 인공와우 착용이 더 효율적인 사실을 다시 한번 확인하였다(Hong et al., 2006). 이러한 결과 는 어음청력검사 결과에서도 두드러지게 나타났는데, 인공와우 착용자가 보장구 미착용 상태에서 평균순음역치를 통해 가장 높은 청력손실을 보였던 것과 달리 어음인지역치에서는 다른 보장구보다 향상된 역치를 보였고 단어인지도에서도 높은 수행 력을 보였던 점이다. 또한 $49.90 \mathrm{~dB} \mathrm{HL}$ 의 평균과 41.86 64.33 $\mathrm{dB} \mathrm{HL}$ 의 범위에 있는 보장구 기능 이득 역치를 고려할 경우, 재 활원 내 교육환경은 적어도 50 80 dB HL 정도의 큰 목소리의 의사소통이나 FM 송수신기 등의 청각보조장치가 필요할 것으 로 생각된다. 특히 본 연구대상 중 약 $10 \%$ 가 어떠한 보장구 착 용도 하고 있지 않아 수화와 구화를 동시에 사용하고자 할 경 우 특단의 보장구가 필요할 것으로 생각된다.

현재 성심농아재활원에서는 보장구 착용 형태를 고려한 재활 은 실시되지 않고 있으나 원생의 특성에 따른 재활이 사용되고 있었다. 그러나 Kim \& Lee(2012)의 청각장애 특수학교의 난청 아동을 대상으로 실험한 연구에서 특수교육대상군일수록 보장 구 착용형태나 의사소통 방식에 따라 적절한 청능재활이 실시 되어야 한다고 보고하였다. 따라서 성심농아재활원의 재활형태 도 보장구의 착용형태와 의사소통 능력에 따라 재활이 차별적 으로 진행되어야 할 것이다. 그 이유는 수화와 구화가 재활원에 서 동시에 사용되고 있어 수화에 익숙한 원생들이 구화를 할 수 있는 상황에서도 이미 익숙한 수화만을 사용할 수도 있기 때 문이다(Kim \& Lee, 2012). 성심농아재활원의 관계자는 원생의 상황에 맞게 재활원 내에서 재활방식을 달리한다고 하였다. 예 를 들어, 의사소통 방식에 따라 발화가 어려워 수화를 사용하는 원생의 경우 음소를 바르게 쓰면서 정확한 수화표현을 할 수 있 도록 유도하고 있으며 발화가 있다면 구화를 더 많이 유도하는 방식을 사용하고 있었다. 이러한 방식은 보장구 기능이득 역치, 보장구의 착용형태, 그리고 의사소통 가능 능력을 구분하여 조 금 더 체계적인 수화와 구화의 사용기준을 규정하고 재활방식 의 유형을 선택하면 더 좋을 것으로 본다.

안타깝게도 재활원 내 절반에 가까운 원생들이 어음인지역 치 및 단어인지도 검사에서 어음을 듣고 따라 말하는 것에 어 려움을 보였다. 따라서 추후 재활원 내의 청력검사를 시행하게 될 경우, 재활원 내 원생의 따라 말하기 수준을 고려하여 어음 인지역치 및 단어인지도 검사 시 그림을 이용하여 검사할 것을 권고한다. 그러한 경우 두 명의 검사자가 재활원생이 검사어음 을 듣고 그림을 정확히 지적하는 경우 정반응으로 간주하여 검 사를 진행하는 방법을 사용하는 것이 좋을 것으로 생각된다. 중 복장애로 인해 SRT를 실시할 수 없을 경우 $\mathrm{SDT}$ 를 이용하였는 데 그러한 경우는 단지 1 명뿐이었다. SDT는 해당 귀의 어음주 파수인 $500,1,000,2,000 \mathrm{~Hz}$ 중에서 가장 반응이 좋았던 청력
역치와 일치하여야 좋은 신뢰도를 보이는 검사결과로 간주한다 (Kaplan et al., 1993). 본 연구에서 보청기를 착용한 후 실시한 $\mathrm{SDT}$ 는 $40 \mathrm{~dB}$ HL로 기능이득 역치인 $50 \mathrm{~dB}$ HL과 $10 \mathrm{~dB}$ 차이 를 보여 일치하는 결과로 나타났다. 따라서 신뢰도는 좋은 것으 로 평가할 수 있다. 본 실태조사에서는 검사 시간이 제한적이었 고 재활원 내에서 보유하고 제공할 수 있는 원생들의 따라 말하 기 수준에 대한 정보가 없었기 때문에 보장구 착용 후 쾌적역치 로 반응하는 60 75 dB HL의 MCL로 가정하여 측정하였고 원 생이 해당 MCL에서 단어인지도를 측정할 수 없을 경우 검사를 시행할 수 없다고 표기하였다. 그러나 앞으로 재활원 내 어음 검 사 시에는 어음을 따라 말하지 못하거나 SDT를 측정할 수 없는 경우, 원생들의 보장구 기능이득 역치를 고려할 뿐만 아니라 각 원생들에 적절한 쾌적역치를 측정하여 어음에 반응할 수 있는 강도가 제시되어야 것으로 생각된다. 또한 $\mathrm{KSA}$ 에서 따라 말하 기가 불가능한 경우 SDT 측정으로 넘어가는 것이 아닌 그림을 이용한 SRT 및 WRS 검사가 시행되어 원생들의 정확한 어음 검사 결과를 측정하여야 할 것으로 사료된다.

IOI-HA 측정결과, 전체 점수 분포는 3.50 4.19점의 분포를 보여 국내 선행논문 3.49점에서 4.41점과 비교할 시 유사한 결 과를 나타내었다(Lee et al., 2005). 최대점수에 다소 차이를 보 이는 것은 수집 대상자의 연령이나 청력에 따른 차이로 사료된 다. 선행연구의 경우 평균 연령이 62세로 청각장애 발생 이후 보장구를 접하기 전까지의 기간이 길어 의사소통의 불편함과 소외감의 경험이 많기 때문에 보장구 착용 후 얻게 되는 효과를 크게 느껴 최대점수가 높은 것이라 생각되나 현 논문의 최대점 수가 낮은 이유로는 대부분의 대상자가 어리고 청력이 더 나쁘 기 때문인 것으로 사료된다. 특히 어린 시기에 보장구를 착용하 기 때문에 청각장애 발생 이후 보장구를 접하기 전까지의 기간 이 길지 않아서 청력손실에 의한 의사소통의 어려움이나 소외감 등에 대한 경험이 적어 보장구로 얻게 되는 효과를 크게 느끼지 못하는 것도 하나의 이유로 생각된다. 또한 선행연구의 경우 인 공와우와 이형 착용자에 관한 IOI-HA 점수는 수집되지 않았기 때문에 이러한 점수차이를 보이는 것이라 사료된다. 국외 IOI$\mathrm{HA}$ 를 적용한 선행연구들은 양이 착용에 대한 효과를 보고하였 는데 중국의 경우, IOI-HA를 통한 양이 착용 효과는 활동의 제 한 정도 문항에서 양이 착용자가 편측 착용자보다 높은 점수를 보였고(Liu et al., 2011), 네덜란드에서는 보청기 사용시간에 관 한 문항에서 양이 착용자가 편측 착용자보다 높은 점수를 보였 으며(Cox et al., 2003), 영국의 경우 편측 착용자보다 양측 착용 자가 양의 상관을 보였다는 보고가 있다(Stephens, 2002). 그러 나 본 논문에서는 보청기의 양이 착용 효과가 나타나지 않았다. 아마도 보장구 착용 형태별로 각 대상자 수가 적어서 일반적인 현상이 나타나지 않았던 것으로 사료된다. 추후 IOI-HA 검사는 
보장구 착용 형태별 대상자 수를 고려할 필요가 있을 것으로 생 각된다. 그러나 검사 시 대화와 질문을 통해 전반적 재활원 내 원 생들은 보장구 착용 형태에 상관없이 보장구에 대해 긍정적인 사고를 가지고 있었던 것으로 사료된다. 본 조사를 통해 재활원 내 원생들의 전반적인 청력 상태를 확인해 볼 수 있었고, IOI$\mathrm{HA}$ 를 이용하여 현재 착용 중인 보장구의 착용시간, 활동의 제 한 정도, 만족도 등을 평가해 볼 수 있었다. 그러나 인공와우 및 보청기의 매핑과 피팅이 어음인지를 하기에 불충분하여 좀 더 정교하고 적절한 인공와우 매핑과 보청기 피팅이 이루어져야 할 것으로 생각된다. 앞으로도 기관의 질 높은 재활 서비스의 질을 향상하고 기관 내 재활원생들의 귀 건강을 예방할 수 있도록 정 기적인 청력검사가 필요할 것으로 생각된다. 본 연구를 통해 각 청각장애에서 원생들의 정기적인 청력검사와 보장구 이득에 대 한 검사가 보장구 착용 형태에 따른 적합 및 만족도나 의사소통 방식의 결정을 할 수 있는 기반이 된다는 점을 확인한 의의가 있다. 또한 청각 및 언어재활의 참여도가 낮고 보장구를 착용하 지 않거나 사용하지 않는 원생들에게 청각 및 언어재활과 보장 구 착용의 효과를 인식하게 할 수 있는 기회로 활용하여 재활 참여도 및 보장구 만족도 향상과 보장구 착용이 더욱 활성화되 기를 기대한다.

중심 단어 : 성심농아재활원·청력손실 상태·청력보장구· 국제 표준 보청기 효과 지수.

\section{REFERENCES}

Cox, R. M., Alexander, G. C., \& Beyer, C. M. (2003). Norms for the International Outcome Inventory for Hearing Aids. Journal of the American Academy of Audiology, 14(8), 403-413.

Hong, B. N., Kim, J. S., Yang, H. S., \& Song, J. H. (2006). Word discrimination abilities for children who use hearing aids and cochlear implants. Audiology and Speech Research, 2(1), 40-47.
Bentler, R., Gustav Mueller, H., \& Rickettes, T. A. (2016). Modern Hearing aids: Verification, Outcome Measures, and Follow-Up. (pp. 665.). San Diego: Plural Publishing, Inc.

Kaplan, H., Gladstone, V. S., \& Lloyd, L. L. (1993). Audiometric Interpretation: A Manual of Basic Audiometry. (2nd ed.). (pp. 282-283). Boston: Allyn and Bacon.

Kim, Y. J. \& Lee, J. H. (2012). A study of the speech and environmental sound recognition in the classroom noise for school-aged children with hearing loss. Audiology and Speech Research, 8(1), 101-110.

Lee, J. H., Cho, S. J., Kim, J. S., Jang, H. S., Lim, D. H., Lee, K. W., et al. (2010). Korean Speech Audiometry (KSA). Seoul: Hakjisa.

Lee, M. A., Kim J. S., \& Ahn J. H. (2005). International Outcome Inventory for Hearing Aids (IOI-HA) Korean version. Korean Journal of Audiology, 9(1), 65-76.

Liu, H., Zhang, H., Liu, S., Chen, X., Han, D., \& Zhang, L. (2011). International Outcome Inventory for Hearing Aids (IOI-HA): Results from the Chinese version. International Journal of Audiology, 50(10), 673-678.

Ministry of Education. (2016, July 18). 2016 Special Education Statistics. Retrived from https://www.moe.go.kr/boardCnts/view.do?boardID=319 \&boardSeq $=63788 \&$ lev $=0 \&$ searchType $=$ null\&statusYN $=$ C\&page $=1 \&$ s $=$ moe $\& \mathrm{~m}=030208 \&$ opType $=\mathrm{N}$.

Ministry of Health and Welfare. (2016a, July 22). Status of registered people with disabilities. Ministry of Health and Welfare. Retrieved from http:// www.mohw.go.kr/front_new/jb/sjb030301vw.jsp?PAR_MENU_ID=03\& MENU_ID=0321\&CONT_SEQ=333547\&page $=1$.

Ministry of Health and Welfare. (2016b, July 29). 2016 Welfare Institutes Table for Disabilities People. Ministry of Health and Welfare. Retrieved from http://www.mohw.go.kr/front_new/jb/sjb0601vw.jsp?PAR_MENU_ ID=03\&MENU_ID=03160501\&CONT_SEQ=333654\&page $=1$.

Ministry of Health and Welfare. (2017, June 22). Status of Registered People with Disabilities. Ministry of Health and Welfare. Retrieved from http:// www.mohw.go.kr/front_new/jb/sjb030301vw.jsp?PAR_MENU_ID=03\& MENU_ID=0321\&CONT_SEQ=340236\&page $=1$.

Stephens, D. (2002). The International Outcome Inventory for Hearing Aids (IOI-HA) and its relationship to the client-oriented scale of improvement (COSI): El Inventario Internacional de Resultados para Auxiliares Auditivos (IOI-HA) y su relatiócute; n con la Escala de Mejoría Orientada hacia el Cliente (COSI). International Journal of Audiology, 41(1), 42-47.

Studebaker, G. A., Sherbecoe, R. L., McDaniel, D. M., \& Gwaltney, C. A. (1999). Monosyllabic word recognition at higher-than-normal speech and noise levels. The Journal of the Acoustical Society of America, 105(4), 2431-2444. 